\title{
U.S. Geological Survey Programs in Louisiana
}

\section{U.S. Department of the Interior - U.S. Geological Survey}

Louisiana has abundant natural resources that include the lower Mississippi River, which is the largest river system in the United States. The State's unique geography and associated ongoing geologic processes are environmentally significant; however, these factors can contribute to coastal erosion, wetland loss, saltwater encroachment into surface and ground waters, land subsidence, and flooding.

Solutions to these varied and challenging earth science problems can be aided by the scientific approach of the U.S. Geological Survey (USGS), which has provided unbiased, technically sound earth science information for more than 100 years. This Fact Sheet is designed to inform citizens about current USGS programs in Louisiana that address relevant earth science needs and issues and provide scientific understanding and information on which decisions can be made to minimize and mitigate the effects of natural hazards and human activities on critical natural resources.

\section{Lake Pontchartrain Basin}

Scientific studies recently begun by the USGS indicate that several key natural processes and human-induced environmental factors are directly affecting the health of Lake Pontchartrain (fig. 1), which is one of America's largest estuaries. The USGS, at the request of the U.S. Congress, began an evaluation of the environmental issues that face the region and developed a multiyear strategic plan to collect the scientific information needed to address them. The specific environmental issues addressed by the study include contamination of sediment and water by chemicals from urban and agricultural sources, lakeshore erosion and loss of grass beds, intrusion of saltwater from canals and navigable waterways into aquifers, and effects of past long-term commercial shell dredging.
The USGS, in cooperation with Louisiana State University (LSU), is documenting the geologic framework of the lake, shoreline contours, and contaminated sediments; developing a computer circulation model; and providing interim results to the public and the planners involved in efforts to restore and protect the Lake Pontchartrain Basin.

In 1984, the U.S. Army Corps of Engineers (USACE) was authorized to construct a diversion canal from the Mississippi River to allow water to flow into Lake Pontchartrain. In response to the concerns of some citizen groups about the effects this would have on Lake Pontchartrain, a multiagency reanalysis committee, which comprises Federal, State, and private representatives, was formed. The USGS helped the committee in the design of an experimental release of Mississippi River water into the lake through the Bonnet Carré Spillway and provided technical expertise on determining the potential effects of this release. Dye studies were conducted and physical conditions of the lake were monitored to determine potential mixing patterns. The USGS also collected water-quality and other hydrologic information to evaluate the effects of the diversion on the aquatic health.

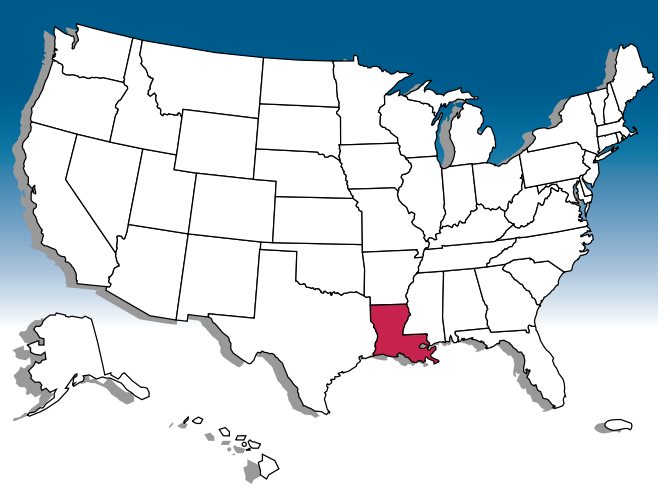

Index of Subjects

Lake Pontchartrain Basin

Coastal Restoration and Wetlands Monitoring

Mercury in Fish

Wetland, Forest, and Animal Ecology

Surface-Water Resources in St.Tammany Parish

Topographic Mapping

Sharing Geospatial Data

Saltwater Encroachment Near Baton Rouge

Digital Raster Graphic Program

Collection of Hydrologic Data

Center for Coastal Geology

Statewide Real-time Flood Monitoring

Earth Science Information Center

\section{Coastal Restoration and Wetlands Monitoring}

The coastal marshes and tidal wetlands of Louisiana's coast and the barrier islands that protect them form one of the world's most productive ecosystems. Louisiana has 25 percent of the vegetated wetlands and 40 percent of the tidal wetlands in the 48 contiguous States. However, the Gulf Coast of Louisiana is eroding faster than any other coastal area of the world. Every year, Louisiana loses as much as 40 square miles of land - an area nearly the size of Washington, D.C. Some of this land loss can be traced to human activity, but much of it can be traced to the forces of nature,

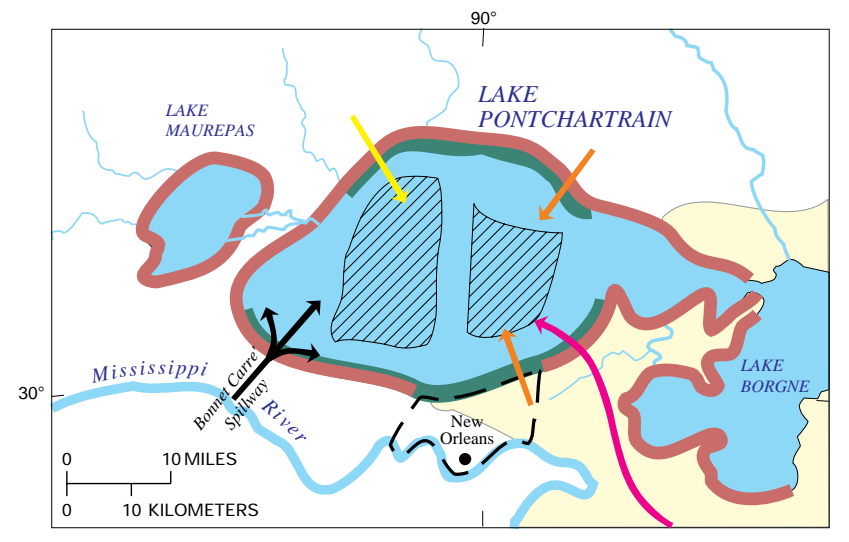

Figure 1. Environmental issues that face Lake Pontchartrain.

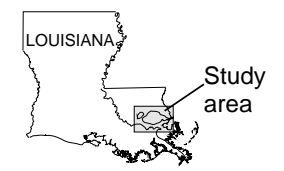

EXPLANATION Major issues

Shoreline erosion and wetland loss

Sediment and water pollution

Saltwater intrusion Shell dredging Freshwater diversion Agriculture runoff

Sewage/municipal runoff

Saltwater intrusion 
which include land subsidence caused, in part, by compaction of the Mississippi River Delta sediments and large storms that strike the area about every 5 years.

Since 1984, the USGS has worked closely with various Federal, State, and local agencies to document coastal erosion and wetland loss. USGS studies have included applied research and monitoring of basic geologic and hydrologic variables to document the causes of and processes responsible for the widespread devastation. Results of these studies are an integral part of the Federal and State Wetlands Task Force, which is spending \$40 million per year in restoring and preserving Louisiana's valuable coastal resources.

USGS scientists play key roles in the design of monitoring programs for the Comprehensive Coastal Wetlands Planning, Protection, and Restoration Act. They serve as technical consultants to other U.S. Department of the Interior agencies, the USACE, the U.S. Environmental Protection Agency (USEPA), and the Office of the Governor of Louisiana on matters that concern geologic, water-quality, and other hydrologic issues, as well as the erosion of barrier islands and wetlands loss.

The USGS, in cooperation with the Louisiana Department of Natural Resources, has installed and operates 19 surface-water monitoring sites at key locations along the Louisiana coast. Data collected at these sites provided Louisiana with vital information on Hurricane Andrew as it tracked along the coast. The data also are used to manage freshwaterdiversion and coastal-restoration projects by the State of Louisiana and the USACE.

\section{Mercury in Fish}

In 1994, the USGS, in cooperation with the Louisiana Department of Environmental Quality, began a study to determine the presence and concentration of mercury in selected fish, water, and bottom sediments from streams and lakes throughout the State. Spanish moss and tree lichens, which are indicators of atmospheric sources of pollution, also were studied. Study sites were selected jointly by the USGS and the State on the basis of historical water, bottom sediment, and tissue data in both agencies' data bases and the recreational and financial importance of large commercial fisheries. Results of sampling have been provided to the Louisiana Department of Health and Hospitals for review and possible health advisory consideration. Four samples indicated mercury levels in fishtissue that were above USEPA (1.0 part per million) and State ( 0.5 part per million) limits.

\section{Wetland, Forest, and Animal Ecology}

The USGS Biological Resources Division (formerly the National Biological Service) conducts research throughout Louisiana on wetland, forest, and animal ecology.

The National Wetlands Research Center (NWRC) at the University of Southwestern Louisiana research park in Lafayette uses geographic information systems (GIS) and remote sensing to monitor wetland change and to plan restoration. Research includes developing wetland-restoration techniques in Yazoo National Wildlife Refuge and Caddo Lake and studying functions in the Kisatchie National Forest; developing models to predict habitat changes at the Felsenthal National Wildlife Refuge and other sites; determining the effectiveness of management practices on restoration and maintenance of coastal wetlands; and studying collaboratively how private industries' water-management affects saltwater and freshwater species. NWRC scientists evaluate planting procedures, research controlling invasive species, study the effects of fire management, and identify natural community processes along the Gulf coastal prairie. Migratory-bird researchers study habitat, behavior, productivity, and landscape feature relations.

Two Cooperative Research Units, one at LSU and one at Grambling State University, in collaboration with other agencies, research bird migrations and habitat use, fishery-resource management and use, and effects of weather patterns on wildlife.

\section{Surface-Water Resources in St. Tammany Parish}

The northern shore of Lake Pontchartrain and especially St. Tammany Parish have undergone extensive population growth in the last decade. Public officials and private citizens are concerned about the effects of this growth on the quality of surface water in the parish and Lake Pontchar- train. Historically, this area has been highly productive for freshwater and saltwater fisheries. However, the capability of the surface water in this area to assimilate everincreasing amounts of wastes from point (sewage-treatment facilities) and nonpoint (residential and agricultural fertilizers) sources has definite limits.

In response to these concerns, the USGS, in cooperation with St. Tammany Parish, recently investigated the effects of population growth on water quality in streams within the Parish. This information can be used to make decisions regarding current and future wastewater management.

\section{Topographic Mapping}

Among the most popular and versatile products of the USGS are its 1:24,000scale topographic maps (1 inch on the map represents 2,000 feet on the ground). These maps depict basic natural and cultural features of the landscape, such as lakes and streams, highways and railroads, boundaries, and geographic names. Contour lines are used to depict the elevation and shape of terrain. Louisiana is covered by 877 maps at this scale, that are useful for civil engineering, land-use planning, naturalresource monitoring, and other technical applications. These maps have long been favorites with the general public for such uses as hiking, camping, exploring, and fishing expeditions. Revision work in progress to update the information on selected 1:24,000-scale topographic maps for Louisiana is shown in figure 2.

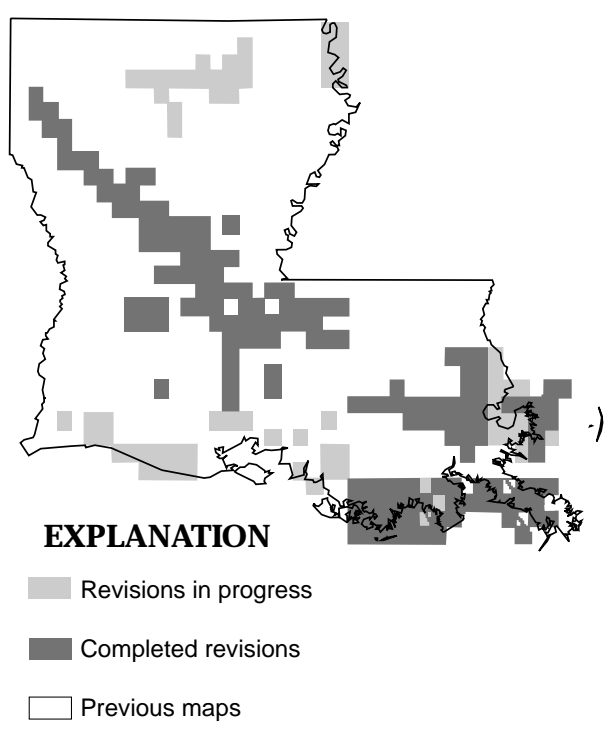

Figure 2. Revision of 1:24,000-scale topographic maps for Louisiana. 
The USGS and the Louisiana Department of Transportation and Development (DOTD) have long worked together to provide the most current and accurate topographic maps possible. Currently, the two agencies have an agreement wherein a new digital revision process is used to revise existing 1:24,000-scale maps and to produce digitized map data for southwestern Louisiana. This new technique allows for timely revision of the topographic map and generates digital data that can be used in GIS.

\section{Sharing Geospatial Data}

The Competitive Cooperative Agreements Program (CCAP) was established by the Federal Geographic Data Committee through the USGS to help form datasharing partnerships with the non-Federal sector. This program provides funding to State and local government agencies, academia, and the private sector to encourage resource-sharing projects through the use of technology, networking, and interagency coordination. The LSU Center for Energy and Environmental Resources has been funded by CCAP to establish a National Spatial Data Infrastructure clearing-house node for Louisiana. The clearing house is a distributed, electronically connected network of geographic and cartographic data producers, managers, and users. The network allows users to find the data they need, evaluate the data for their application, and obtain the data as economically as possible.

\section{Saltwater Encroachment Near Baton Rouge}

Because of large withdrawals from the aquifer system in the Baton Rouge area, ground-water flow patterns have been altered over the years. Saltwater now encroaches into formerly freshwater areas, which could destroy their usefulness for public and most industrial supplies. The aquifers in the Baton Rouge area supply water for about 360,000 people and large, economically critical industries.

A recent study by the USGS, in cooperation with the DOTD and the Capital Area Ground Water Conservation Commission, showed that the quality of ground water at two public supply pumping centers will soon be affected by saltwater encroachment (fig. 3). Local officials are concerned about the impending encroachment and are planning strategies that are based on results of USGS studies to protect these water supplies. Currently, plans are underway at the USGS for expansion of ground-water data-collection activities to monitor the effects of remedial saltwater-diversion strategies.

\section{Digital Raster Graphic Program}

The USGS and the National Park Service (NPS) have established an interagency agreement to produce digital raster graphics (DRG's) for barrier islands along the Gulf Coast east of New Orleans. The DRG's are inexpensive digital products, scanned from USGS topographic maps, that can be used as an accurate base for a geographic information system. A private company is producing the DRG's for the USGS and participating agencies under an innovative Federal/private partnership. DRG's are prepared for all 1:24,000-, $1: 100,000-$, and 1:250,000-scale topographic maps that cover the NPS area of interest. The DRG's are available to the public on CD-ROM.

\section{Collection of Hydrologic Data}

The USGS, in cooperation with more than 13 Federal, State, and local agencies, collects streamflow, water-quality, and ground-water data at sites throughout the State. These data are critical for the dayto-day administration and management of water resources, determination of the extent and severity of droughts, characterization and prediction of floods, and monitoring of the effects of human activities on streamflow, ground water, and water quality. These data also are essential to interpretive studies, the results of which are used by numerous other agencies to make decisions about water issues that affect millions of people.

\section{Center for Coastal Geology}

In 1988, the USGS Center for Coastal Geology and Regional Marine Studies was established in cooperation with the University of South Florida. The center conducts a wide variety of research on coastal and regional marine problems in the States that border the Gulf of Mexico. These problems, which are of particular interest in

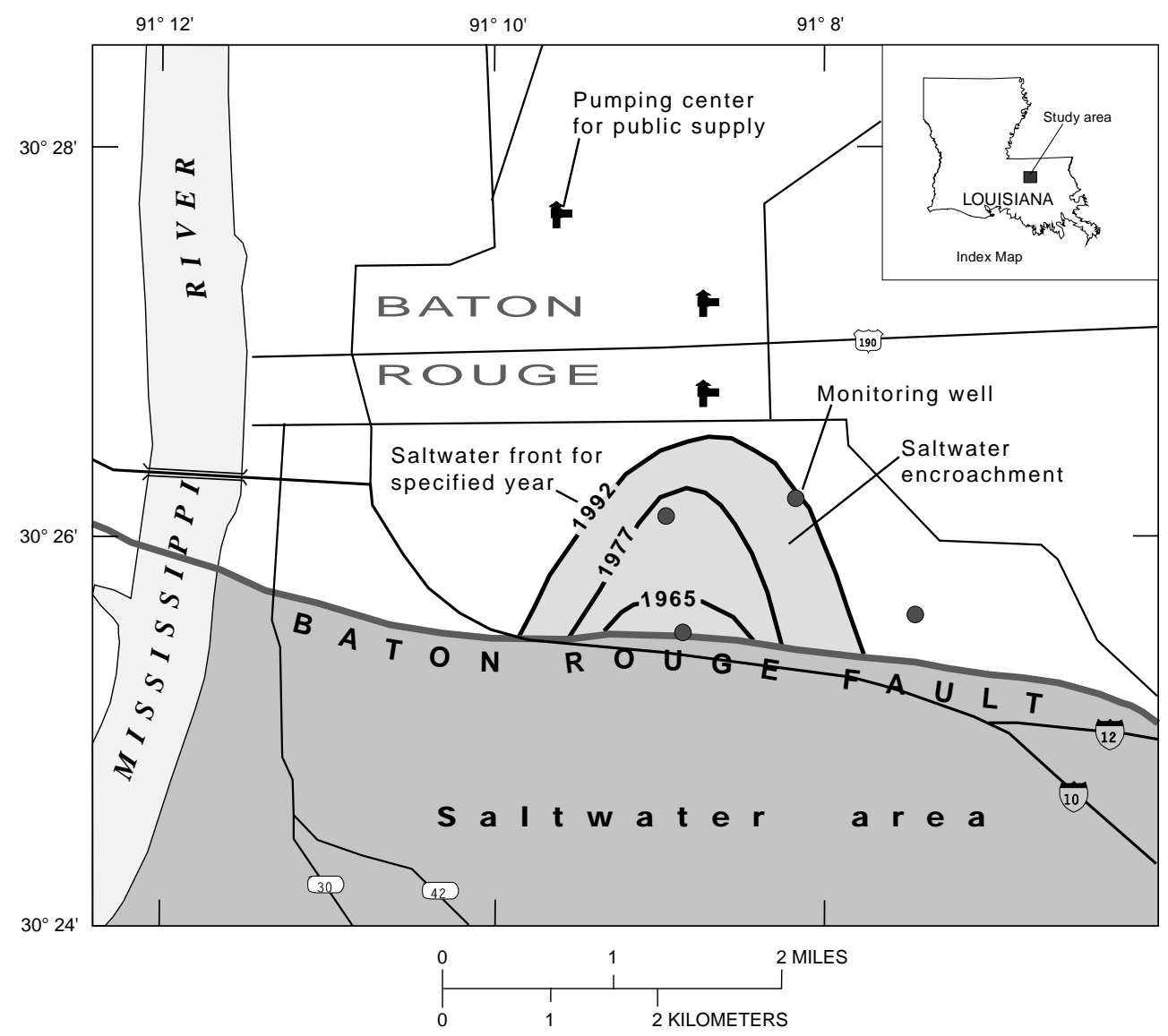

Figure 3. Saltwater encroachment in the "1,500 foot" aquifer toward pumping centers. 
Louisiana's coastal wetlands, include coastal erosion, climate change, wetlands deterioration, coastal pollution, and hardmineral resources. With increased understanding of these problems, future coastal erosion, the fate of wetlands, where polluted sediments accumulate, and the location of economically valuable hard minerals can be more accurately predicted.

\section{Statewide Real-time Flood Monitoring}

Louisiana leads the Nation in property damage caused by floods. To reduce future losses, the USGS, in cooperation with Federal, State, and local agencies, operates a statewide real-time flood monitoring network. Currently, the USGS monitors 101 USGS and USACE gaging stations throughout the State to measure river stage and to transmit data directly on a real-time basis by means of radio and satellite relay technology (fig. 4). During floods, this information is passed on to the appropriate emergency response agencies and the news media through the Louisiana Office of Emergency Preparedness.

A flood-tracking map, which was modeled on a hurricane-tracking map, has been prepared for the Amite River Basin near Baton Rouge. The map was a joint effort among the USGS, the Amite River Basin Commission, a local television station, and other local businesses and was distributed through fast-food outlets to the public. People living in potentially affected areas can use these maps and the USGS hydrologic information provided through the news media to make decisions about evacuation and protection of personal property.

\section{Earth Science Information Center}

The USGS Earth Science Information Centers (ESIC) provide information about the USGS, its programs, products, and technological developments to the public. The ESIC at the Louisiana Geological Survey (LGS) at LSU in Baton Rouge was established under a cooperative agreement between the USGS and the LGS. As part of the national ESIC network, these offices provide information on such earth science topics as cartography, geography, digital data, remote sensing, geology, geophysics, geochemistry, hydrology, geohydrology, aerial photography, and land use. The offices also have USGS map products available for purchase.

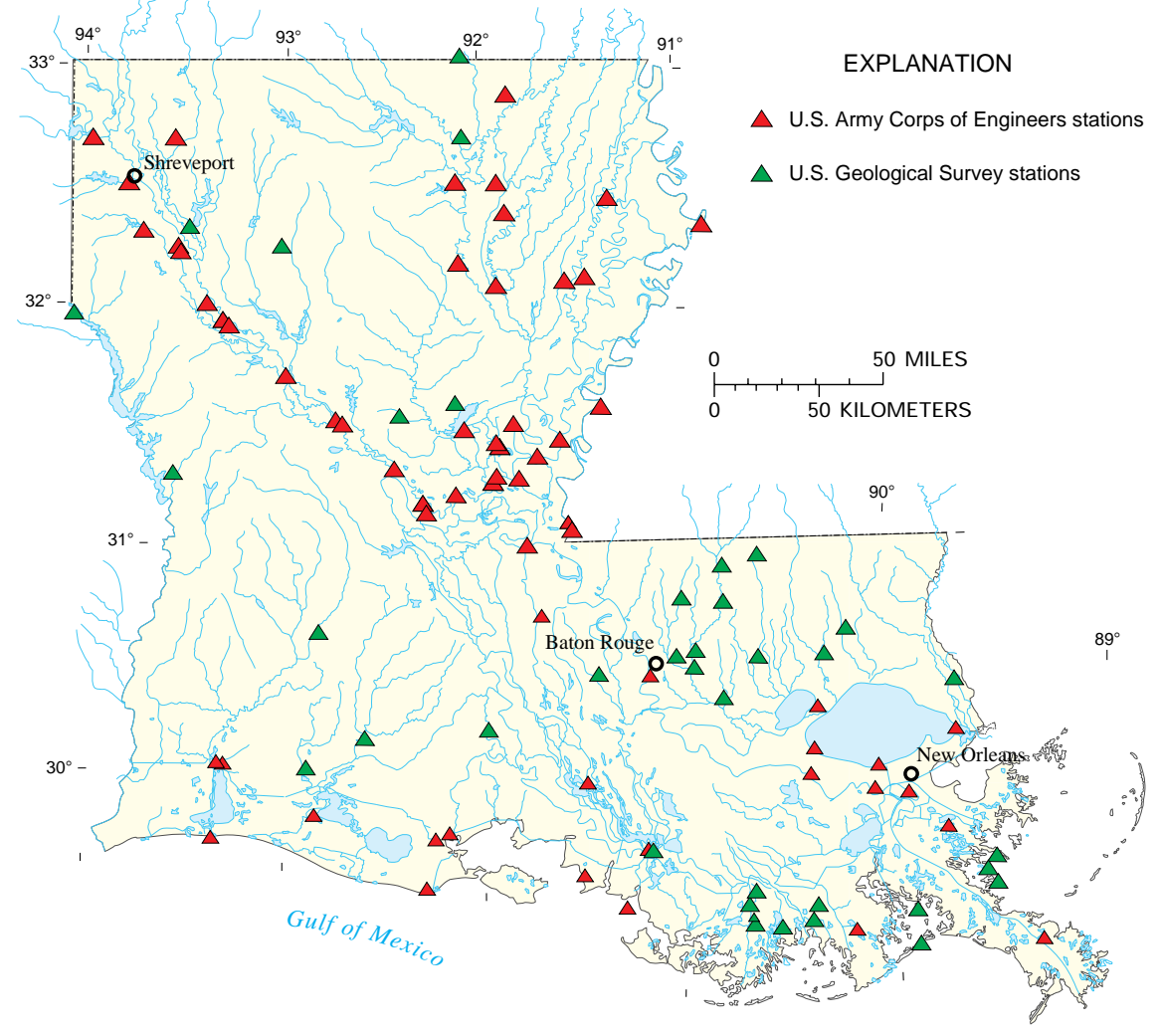

Figure 4. Statewide real-time flood-monitoring network.

\section{For More Information}

USGS State representative 3535 S. Sherwood Forest Blvd.

Suite 120

Baton Rouge, LA 70816

(504) 389-0281 ext. 3107

Fax: (504) 389-0706

Email: dc_la@usgs.gov

Additional earth science information can be found by accessing the USGS Home Page on the World Wide Web at http://www.usgs.gov/

For more information on all USGS reports and products (including maps, images, and computerized data), call 1-800-USA-MAPS

The USGS provides maps, reports, and information to help others meet their needs to manage, develop, and protect America's water, energy, mineral, biological, and land resources. We help find the natural resources needed to build tomorrow, and supply the scientific understanding needed to help minimize or mitigate the effects of natural hazards and environmental damage caused by natural and human activities. The results of our efforts touch the daily life of almost every American. 